\title{
POTENSI PULAU GILIGENTING SEBAGAI KAWASAN EKOWISATA DI SUMENEP JAWA TIMUR
}

\author{
Muhammad Imam Wicaksono $^{1}$, Sunarto ${ }^{2}$, I Gusti Ayu Ketut Rachmi Handayani ${ }^{3}$ \\ ${ }^{1}$ Program Pascasarjana Ilmu Lingkungan, Universitas Sebelas Maret Surakarta, \\ wicaksono.imam.muh@gmail.com \\ ${ }^{2}$ Program Studi Biologi, Fakultas Matematika dan Ilmu Pengetahuan Alam, Universitas \\ Sebelas Maret Surakarta,rm.sunarto@staff.uns.ac.id \\ ${ }^{3}$ Program Studi Hukum, Fakultas Hukum, Universitas Sebelas Maret Surakarta, \\ ayu_igk@staff.uns.ac.id
}

\begin{abstract}
ABSTRAK
Pengembangan kawasan ekowisata perlu upaya perencanaan pengelolaan kawasan. Upaya pengelolaan dan perencanaan kawasan pariwisata bertujuan untuk mendorong dilakukannya pengawetan lingkungan hidup, sehingga ekowisata perlu di rencanakan. Kajian tentang potensi Pulau Giligenting dilaksanakan mulai Februari hingga Mei 2018. Penelitian dilakukan di Kabupaten Sumenep serta di Pantai Sembilan Pulau Giligenting. Metode penelitian yang digunakan yakni kajian data sekunder dengan menggunakan penelitian yang telah dilakukan, observasi langsung dan wawancara bebas kepada Pegawai Pemerintahan maupun masyarakat. Alat yang digunakan pada kajian ini antara lain alat komunikasi, bolpoin, notulen, flashdisk, serta camera untuk dokumentasi. Potensi yang dimiliki oleh Pulau Giligenting sebagai kawasan ekowisata antara lain terumbu karang, pantai Sembilan, dan tanaman bidara.
\end{abstract}

Kata Kunci: Ekowisata, Pulau Giligenting.

\begin{abstract}
The development of ecotourism region needs an effort of regional management planning. The effort of management and planning the tourism region to encourage an environmental conservation, therefore, ecotourism needs to be planned. The study on the potentials of Gili Genting Island was conducted from February to May 2018 The research was performed in Sumenep Regency and at Sembilan Beach on Giligenting Island. The research method employed was a secondary data study by using a previously conducted research, direct observation, and free interviews with Government officials and society. The research tools used in the research were communication tools, ballpoint, note taker, flash disk, and camera for documentation. The potentials of Gili Genting Island as the ecotourism regions are coral reefs, Sembilan Beach, and Bidara plants.
\end{abstract}

Keyword : ecotourism, Giligenting island

\section{PENDAHULUAN}

Sektor pariwisata merupakan salah satu kegiatan perekonomian potensial dimana merupakanprioritas pengembangan bagi sejumlah negara, terlebih bagi negara berkembang seperti Indonesia. Pengembangan kawasan pariwisata alam lestari dan berkelanjutan memerlukan kesinergian antara multistakeholder dalam penanganan serta pengelolaan sumberdaya.
Provinsi Jawa Timur memiliki destinasi wisata yang beragam.

Salah satu kabupaten dengan luas kawasan kepulauan yakni Kabupaten Sumenep. Kabupaten Sumenep merupakan kabupaten di provinsi Jawa Timur yang berada diujung timur Pulau Madura. Secara administrasi Kabupaten Sumenep terdapat 27 Kecamatan terdiri dari 19 Kecamatan daratan dan 8 Kecamatan kepulauan.

ISSN: 2355-6587, e-ISSN: 2528-2220

http://ejournal.bsi.ac.id/ejurnal/index.php/jp 
Berdasarkan hasil sinkronisasi luas Kabupaten Sumenep (2002) terdapat 126 pulau yang tersebar membentuk gugusan pulau (48 pulau berpenghuni dan 78 pulau tidak berpenghuni). Secara astronomis Kabupaten Sumenep terletak di $113^{\circ} 32^{\prime}$ 116 $16^{\prime}$ Bujur Timur dan $4^{\circ} 55^{\prime}-7^{\circ} 24^{\prime}$ Lintang Selatan serta memiliki batas administrasi sebagai berikut:

Selatan : Selat Madura

Utara : Laut Jawa

Barat : Kabupaten Pamekasan

Timur : Laut Jawa dan Laut Flores

Penduduk di Kabupaten Sumenep pada tahun 2016 mencapai 1.076.805 jiwa (512.211 Laki laki, 564.594 Perempuan) dengan luas total wilayah $2.093,47 \mathrm{~km}^{2}$. Pulau Giligenting merupakan suatu kecamatan kepulauan di Kabupaten Sumenep. Pulau Giligenting merupakan bagian dari Kabupaten Sumenep memiliki kondisi alam baik untuk dijadikan kawasan ekowisata. Pulau Giligenting saat ini menjadi salah satu destinasi unggulan di kawasan Pulau Madura.

\section{KAJIAN LITERATUR}

Ekowisata merupakan salah satu kegiatan untuk mengeksplorasi suatu kawasan pariwisata yang berada disuatu kawasan, dengan tujuan untuk meningkatkan kesejahteraan masyarakat namun masih mengedepankan kearofan lokal, terjaganya kondisi alam dan dalam pengembangannya melibatkan peran aktif masyarakat dalam segala aspek (Tanaya \& Rudiarto, 2014). Pengembangan kawasan pariwisata memiliki beberapa aspek yang wajib diperhatikan dan telah tercantum dalam sapta pesona.

Pengembangan kawasan ekowisata perlu upaya perencanaan pengelolaan kawasan. Upaya pengelolaan dan perencanaan kawasan pariwisata bertujuan untuk mendorong dilakukannya pengawetan lingkungan hidup, sehingga ekowisata perlu di rencanakan pengelolaannya dengan mengintergrasikan dalam pendekatan sistem untuk konservasi yang menggunakan desain konservasi. Industri pariwisata merupakan salah satu penyumbang pendapatan asli daerah (PAD). Namun banyak kegiatan industri pariwisata menyebabkan kerusakan lingkungan dan mengganggu ekosistem (Iswandi, 2009).

Potensi pada sektor pariwisata Indonesia yang beragam, mulai dari pariwisata alam dan pariwisata adat atau kebudayaan. Hal ini terjadi karena Indonesia merupakan negara dengan suku dan adat beragam di dalamnya, akan tetapi meskipun potensi sektor pariwisatanya sangat berlimpah namun masih banyak pariwisata di daerah yang belum mendapatkan perhatian khusus dari pemerintah. Hal tersebut menyebabkan sektor pariwisata yang seharusnya menjadikan dayatarik wisatawan untuk berkunjung ke daerah tersebut masih belum maksimal pada proses pengelolaannya (Ferdinan et al., 2012).

Metode untuk mendapatkan data pada penelitian tentang potensi kawasan Pulau Giligenting dengan menggunakan data sekunder berupa penelitian yang telah dilakukan, observasi dan wawancara. Review literatur ini bertujuan untuk membangun dan mengkonstruksi konsepsi secara lebih kuat berbasis penelitian-penelitian empiris yang pernah dilakukan (Tjahjono, 2015).

Observasi merupakan salah satu metode pengumpulan data. Metode observasi berguna untuk merekam aktivitas yang bersifat proses yang sedang berlangsung. Secara teknik sudut pandang metode observasi terdapat metode langsung, dan metode tidak langsung. Metode observasi langsung merupakan metode yang dilakukan apabila peneliti terlibat langsung dalam prosesnya, sedangkan observasi tidak langsung peneliti tidak terlibat langsung dalam proses.

Menurut tekniknya observasi dibedakan menjadi observasi terbuka. Observasi terfokus, observasi terstruktur, observasi terstruktur dan observasi sistematis. Observasi terbuka bersifat bebas dimana peneliti dapat mengeksplorasi apa yang di dapatkan. Observasi terstruktur yakni observasi yang sudah dibuatkan point 
khusus sehingga peneliti tinggal member check list pada apa yang dilihat. Observasi terfokus yakni observasi yang merekam seluruh kegiatan yang terjadi sedangkan observasi tersistematis yakni observasi yang telah memiliki aturan bakunya (Purnomo, 2011).

Wawancara merupakan salah satu metode dalam pengumpulan data secara kualitatif. Berdasarkan jenisnya wawancara terdapat wawancara tidak terstruktur, wawancara semi terstruktur dan wawancara bersifat standard. Wawancara tidak terstruktur merupakan wawancara yang tidak terikat suatu pertanyaan khusus, namun wawancara ini bertujuan untuk mendapatkan data yang sebanyakbanyaknya karena bersifat fleksibel. Wawancara tidak terstruktur efektif pada objek yang diwawancara lebih dari satu kali.

Wawancara semi terstruktur yakni wawancara yang sudah disiapkan pedoman tertentu untuk membatasi informasi hanya yang dibutuhkan. Wawancara bersifat standard yakni teknik wawancara yang memiliki patokan pasti sesuai dengan standar yang ada. Namun peneliti jarang melakukan teknik wawancara berstandar karena tidak kayanya data yang diperoleh (Rahmawati, 2007).

\section{METODE PENELITIAN}

Kajian tentang potensi Pulau Giligenting dilaksanakan mulai Februari hingga Mei 2018. Penelitian dilakukan di Kabupaten Sumenep serta di Pantai Sembilan Pulau Giligenting. Metodelogi penelitian yang digunakan yakni deskriptif kualitatif dengan kajian data sekunder penelitian terdahulu, observasi langsung dan wawancara bebas kepada pegawai pemerintahan maupun masyarakat. Alat yang digunakan pada kajian ini antara lain alat komunikasi, bolpoin, notulen, flashdisk serta camera untuk dokumentasi.

\section{PEMBAHASAN}

Bagian ini memuat data (dalam bentuk ringkas), analisis data dan interpretasi terhadap hasil. Pembahasan dilakukan dengan mengkaitkan studi empiris atau teori untuk interpretasi. Ilustrasi hasil penelitian dapat berupa grafik/tabel/gambar yang diberi keterangan secukupnya agar mudah dimengerti.

Akses transportasi untuk menuju ke Pulau Giligenting menggunakan kapal yang disediakan oleh jasa penyebrangan di Pelabuhan Rakyat Tanjung. Pelabuhan Tanjung merupakan dermaga terdekat untuk menuju kawasan pulau Giligenting. Terdapat 2 jenis kapal yang dapat digunakan untuk akses penyebrangan yakni Speedboat dan kapal nelayan. Biaya yang dikeluarkan untuk sekali menyebrang dari pelabuhan Tanjung menuju Pulau Giligenting yakni Rp 10.000 (kapal Nelayan) dan $\mathrm{Rp}$ 300.000/boat (speed boat). Waktu tempuh penyeberangan apabila menggunakan speed boat sekitar 15-20 menit sedangkan jika menggunakan kapal nelayan 30-45 menit. Penyebrangan dari Pulau Madura ke Pulau Giligenting dibuka mulai pukul 07.00 wib dan dari Pulau Giligenting menuju Pulau Madura terakhir Pukul 16.00 wib.

Dermaga di pulau Giligenting berjarak kurang lebih 5 menit dari Pantai Sembilan. Pantai Giligenting merupakan pantai unggulan di kawasan Pulau Giligenting khususnya dan saat ini menjadi salah satu unggulan di kawasan Pulau Madura. Pulau Giligenting memiliki ciri khas pasir putih yang indah dan arus ombak pantai yang kecil dan tenang.

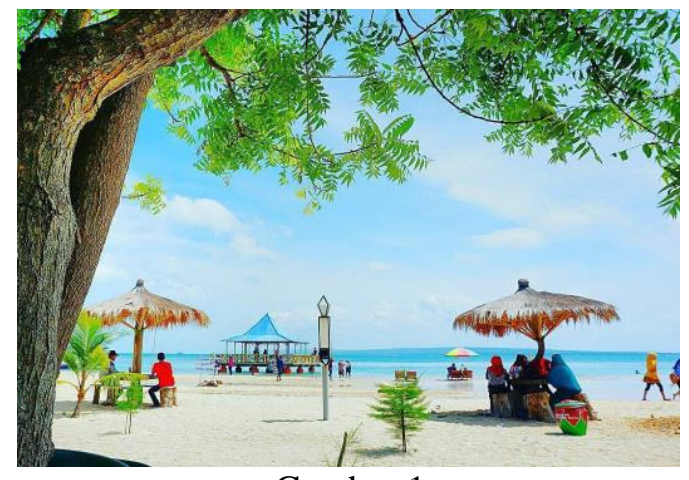

Gambar 1

Suasana Pantai Sembilan Sumber: Dok. Pribadi 
Pantai Sembilan terdapat dikawasan Desa Bringsang Kecamatan Giligenting. Pengembangan kawasan Pantai Sembilan dilakukan dimulai pada tahun 2016. Pengembangan kawasan wisata Pantai Sembilan dilakukan oleh Bapak Sultan selaku investor menggunakan dana pribadi bekerjasama dengan BUMDES Desa Bringsang. Berdasarkan hasil wawancara dengan beliau, proses pembuatan Pantai Sembilan karena melihat kawasan Gililabak yang menjadi kawasan ekowisata terlebih dahulu. Sehingga untuk menunjang kawasan Pulau Gililabak maka dibuatlah kawasan wisata Pantai Sembilan sehingga para wisatawan local maupun international yang berkunjung ke kawasan Sumenep mendapatkan destinasi yang beragam.

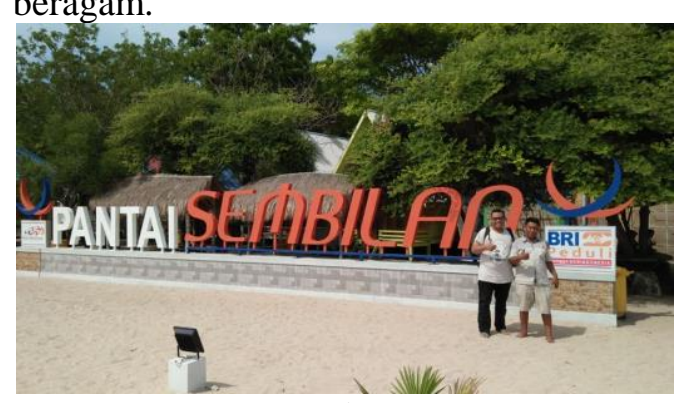

Gambar 2

Diskusi bersama Bapak Sultan sebagai Investor dan Kades Bringsang

Sumber: Dok. Pribadi

Badan usaha milik desa memiliki tujuan untuk mensejahterakan masyarakat desa. Peraturan yang mendasari pembentukan BUMDes terdiri dari undang-undang, peraturan pemerintah, hingga peraturan menteri. Jika diperlukan untuk mengatur lebih lanjut, pemerintah daerah dapat membentuk peraturan daerah tentang BUMDes. Demikian pula ditingkat desa, dapat dibuat peraturan desa tentang BUMDes sesuai dengan keadaan dan kekhasan desa masing-masing (Ridlwan, 2013).

Secara yuridis, peraturan di daerah tentang BUMDes berdasarpada UU No. 32 tahun 2004 tentang Pemerintahan Daerah Pasal 213 ayat (1) "Desa dapat mendirikan badan usaha milik desa sesuai dengan kebutuhan dan potensi desa". Rumusan yang sama diatur dalam PP No. 72 Tahun 2005 tentang Desa. Kemajuan ekonomi akibat adanya pengelolaan kawasan Pantai Sembilan mendapatkan perhatian pemerintah daerah. Hal ini dibuktikan dengan adanya penambahan fasilitas umum penunjang yang di sponsori oleh perbankan maupun dinas di Kabupaten Sumenep.

Pengelolaan sampah di kawasan Pantai Sembilan bertujuan untuk menjaga kelestarian alam serta kebersihan yang menjadi ciri khas Pulau Giligenting. Obyek wisata Pantai Sembilan memiliki aturan tidak tertulis yakni tidak boleh beredar minuman keras maupun pakaian yang terlalu vulgar. Hal ini dikarenakan mayoritas penduduk Pulau Giligenting beragama Islam dan taat dalam menjalankan ibadah. Sehingga diharapkan kemajuan kawasan ekowisata Pantai Sembilan tidak merusak tatanan kehidupan beragaman dan bermasyarakat yang ada di Pulau Giligenting.

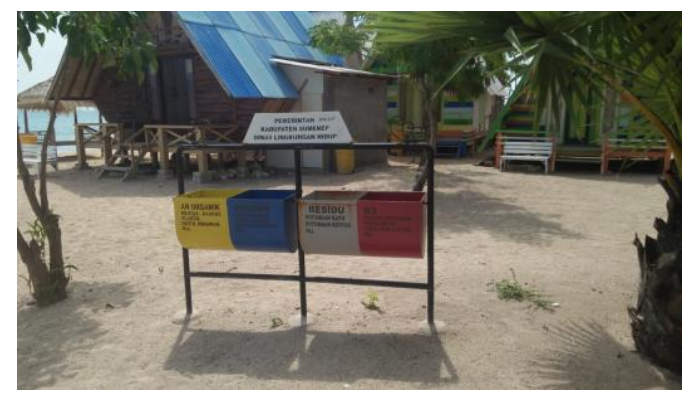

Gambar 3

Penyortiran Sampah Pengunjung oleh Dinas Lingkungan Hidup Sumber: Dok. Pribadi

Pemerintah Kabupaten Sumenep melalui dinas lingkungan hidup berupaya untuk memperbaiki kondisi terumbu karang di kawasan perairan madura terutama kawasan Pulau Giligenting. Transplantasi/pencangkokan terumbu karang bertujuan untuk merehabilitasi terumbu karang rusak yang sebagian besar disebabkan oleh penangkapan ikan dengan menggunakan bom dan potasium. Metode pencangkokan dengan menggunakan media substrat dimana substrat tersebut ditempatkan pada frame ukuran 100 x $80 \mathrm{x}$ 
$20 \mathrm{~cm}$ dan setiap framenya terdapat 12 (dua belas) buah substrat. Namun setelah tahun 2010 sudah tidak menggunakan media frame lagi, tetapi menggunakan substrat dengan ukuran $20 \times 20 \times 20 \mathrm{~cm}$. Jenis terumbu karang yang dilakukan transplantasi adalah Acropora sp.

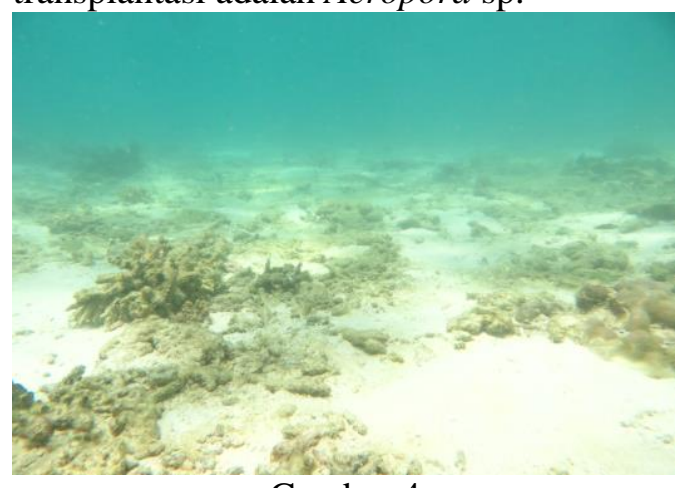

Gambar 4

Kerusakan Terumbu Karang Akibat

Potasium di Giligenting (DLH 2017)

Sumber: Dinas Lingkungan Hidup 2017

Ekosistem terumbu karang merupakan sesuatu kawasan yang dibangun oleh biota laut penghasil kapur, terutama oleh hewan karang, bersama-sama dengan biota lain yang hidup di dasar laut maupun kolom air. Karang memiliki struktur tubuh yang terdiri dari polip dan skeleton. Pada bagian polip terdapat tentakel untuk menangkap plankton sebagai sumber makanan. Setiap polip karang mengsekresikan zat kapur $\mathrm{CaCO}_{3}$ yang membentuk kerangka skeleton karang.

Berdasarkan data yang diperoleh dari Dinas Lingkungan Hidup Kabupaten Sumenep (2017), Transplantasi/ pencangkokan terumbu karang yang telah dilaksanakan:

Perkembangan dan bertahannya terumbu karang dipengaruhi oleh beberapa faktor antara lain:

1. Suhu perairan dari habitat terumbu karang. Terumbu karang dapat hidup pada suhu diatas $180 \mathrm{C}$ namun memiliki suhu ideal berkisar 270C-290C. Apabila suhu melebihi suhu ideal akan menimbulkan pemutihan pada karang, jika hal ini terus berlangsung maka karang akan mengalami kematian.

2. Karang dapat bersimbiosis dengan alga zooxanthellar yang dapat hidup di dalam jaringan karang sehingga memerlukan cahaya matahari. Cahaya matahari diperlukan untuk proses fotosintesis, sehingga karang dapat tumbuh dan berkembang dengan baik pada daerah kedalaman laut yang masih menerima sumber cahaya matahari yakni tidak lebih dari $50 \mathrm{~m}$.

3. Salinitas atau kadar garam yang mencukupi untuk tumbuh kembangnya karang.

4. Polip pada tubuh karang sangat rentan dengan adanya sadimentasi. Sadimentasi dapat menutupi pori polip pada karang yang lambat laun akan mematikan karang. Oleh karena itu, karang tidak dapat tumbuh dan berkembang pada daerah dengan sadimentasi tinggi.

5. Arus air laut yang membantu pertukaran oksigen serta mampu membersihkan polip kerang dari tumpukan sadimentasi membantu tumbuh berkembangnya karang. Daerah yang menghadap laut lepas akan menyebabkan karang sukar untuk tumbuh dan berkembang akibat arus yang begitu besar.

6. Planula pada tubuh karang memerlukan substrat untuk menempel. Karang memerlukan substrat yang kuat untuk tumbuh dan berkembang.

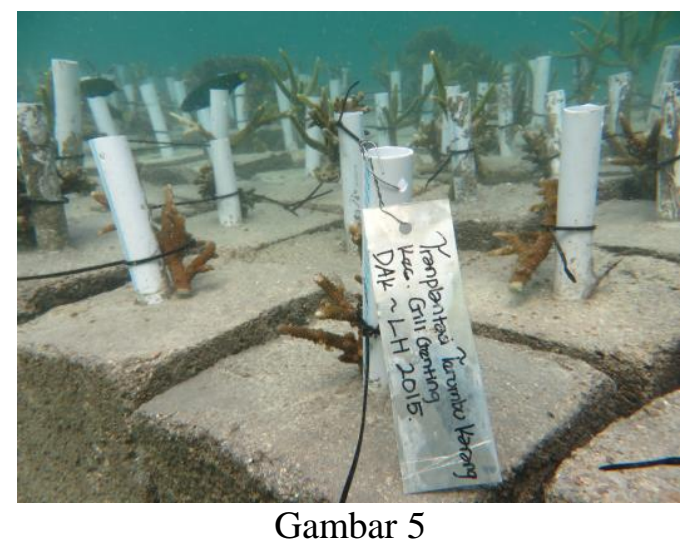

Transplantasi Terumbu Karang 2015 Sumber: Dinas Lingkungan Hidup 2018

Landasan hukum Republik Indonesia dalam mengelola kawasan perairan dan pulau terpencil terdapat dalam UU nomor

ISSN: 2355-6587, e-ISSN: 2528-2220

http://ejournal.bsi.ac.id/ejurnal/index.php/jp 
27 Tahun 2007 Tentang kawasan perariran dan pulau pulau terpencil. Berdasarkan UU Nomor 27 tahun 2007 pasal 28 ayat 1 sampai ayat 7 menyebutkan antara lain:

1. Konservasi Wilayah Pesisir dan PulauPulau Kecil diselenggarakan untuk
a. menjaga kelestarian Ekosistem Pesisir dan Pulau-Pulau Kecil;
b. melindungi alur migrasi ikan dan biota laut lain;

c. melindungi habitat biota laut; dan

d. melindungi situs budaya tradisional.

2. Untuk kepentingan konservasi sebagaimana dimaksud pada ayat (1), sebagian Wilayah Pesisir dan PulauPulau Kecil dapat ditetapkan sebagai Kawasan Konservasi.
a. sumber daya ikan;

b. tempat persinggahan dan/atau alur migrasi biota laut lain;

c. wilayah yang diatur oleh adat tertentu, seperti sasi, mane'e, panglima laot, awig-awig, dan/atau istilah lain adat tertentu; dan

d. ekosistem pesisir yang unik dan/atau rentan terhadap perubahan.

3. Kawasan konservasi sebagaimana dimaksud pada ayat (2) yang mempunyai ciri khas sebagai satu kesatuan Ekosistem diselenggarakan untuk melindungi:

4. Kawasan Konservasi di Wilayah Pesisir dan Pulau-Pulau Kecil ditetapkan dengan Peraturan Menteri.

5. Pengelolaan Kawasan Konservasi sebagaimana dimaksud pada ayat (2) dilaksanakan oleh Pemerintah atau Pemerintah Daerah berdasarkan kewenangan sesuai dengan peraturan perundang-undangan.

6. Untuk mencapai tujuan sebagaimana dimaksud pada ayat (1), Menteri menetapkan:
a. kategori Kawasan Konservasi;
b. Kawasan Konservasi nasional;
c. pola dan tata cara pengelolaan Kawasan Konservasi; dan
d. hal lain yang dianggap penting dalam pencapaian tujuan tersebut.

7. Pengusulan Kawasan Konservasi sebagaimana dimaksud pada ayat (3) dapat dilakukan oleh perseorangan, kelompok masyarakat, dan/atau oleh Pemerintah/Pemerintah Daerah berdasarkan ciri khas Kawasan yang ditunjang dengan data dan informasi ilmiah.

\section{PENUTUP}

Hasil kajian tentang potensi Pulau Giligenting sebagai kawasan ekowisata ditunjang dengan kondisi alam berupa Pantai Sembilan yang telah dikembangkan sebagai kawasan wisata pantai. Terumbu karang masih memiliki karakter alami dan beberapa lokasi sudah dilakukan penanaman substrat terumbu karang serta adanya pohon bidara dengan manfaat yang dapat diolah menjadi sari buah maupun teh sehingga dapat meningkatkan pendapatan masyarakat sekitar.

\section{REFERENSI}

Ferdinan, Y., Makmur, M., \& Ribawanto, H. (2012). Pengembangan Wisata Alam Berbasis Ekowisata dalam Perspektif Pelayanan Publik(Studi Disparbud Kabupaten Nganjuk). Jurnal Administrasi Publik (JAP) Vol 1 No 12 , 2123-2127.

Hung, C.Y. and Yen, G. C. 2002. Antioxidant Activity of Phenolic Compounds

Purnomo, B. H. (2011). Metode dan Teknik Pengumpulan Data dalam Penelitian Tindakan Kelas (Classroom Action Reasearch). Pengembangan Pendidikan, Vol.8 No.1, 251-256.

Rahman, F. (2014). Keanekaragaman dan Tutupan Terumbu Karang di Pulau Giligenting Kabupaten SumenepMadura. Malang: Jurusan Biologi Fakultas Sains dan Teknologi UIN Maulana Malik Ibrahim.

Rahmawati, I. N. (2007). Pengumpulan Data dalam Penelitian Kualitatif: Wawancara. Jurnal Keperawatan Indonesia Vol 11 No 1, 35-40.

Ridlwan, Z. (2013,). Payung Hukum Pembentukan BUMDes. Fiat Justitia Jurnal Ilmu Hukum Volume 7 No. 3, ISSN 1978-5186. 
Sumenep, T. K., \& Brawijaya, F. P. (2017). Pemanfaatan Daun dan Buah Bidara (BUKOL). Sumenep: Bappeda Kabupaten Sumenep.

Tanaya, D. R., \& Rudiarto, I. (2014). potensi pengembangan ekowisata berbasis masyarakat. Jurnal Teknik PWK , 71-81.

Tjahjono, H. K. (2015). Studi Literatur Pengaruh Keadilan Distributif dan Keadilan Prosedural Pada Konsekuensinya Dengan Teknik Meta Analisis. Jurnal Psikologi Fakultas Psikologi Universitas Gajah Mada ISSN:0215-8884 , Vol 35 No.1 21049 .

\section{BIODATA PENULIS}

Muhammad Imam Wicaksono. Saat ini tengah menempuh pendidikan di Universitas Sebelas Maret Surakarta. Program Pascasarjana Ilmu Lingkungan Sosiologi.

Sunarto. Staff akademik Universitas Sebelas Maret Surakarta. Program Studi Biologi. Fakultas Matematika dan Ilmu Pengetahuan Alam.

I Gusti Ayu Ketut Rachmi Handayani. Staff akademik Universitas Sebelas Maret Surakarta. Program Studi Hukum. Fakultas Hukum. 